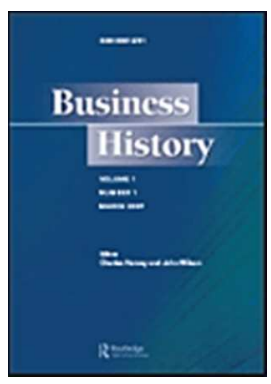

Martin Wilcox

\title{
'To Save the Industry from Complete Ruin' : Crisis and Response in British Fishing 1945-1951
}

\begin{tabular}{|r|l|}
\hline Journal: & Business History \\
\hline Manuscript ID & FBSH-2016-0190.R2 \\
\hline Manuscript Type: & Original Article \\
\hline Keywords: & Fisheries, Labour, productivity, crisis, reorganisation, industrial policy \\
\hline & \\
\hline
\end{tabular}

\section{SCHOLARONE \\ Manuscripts}

This is an Accepted Manuscript of an article published by Taylor \& Francis in Business History on 20 Mar 2019, available online: http://www.tandfonline.com/10.1080/00076791.2019.1576634. 


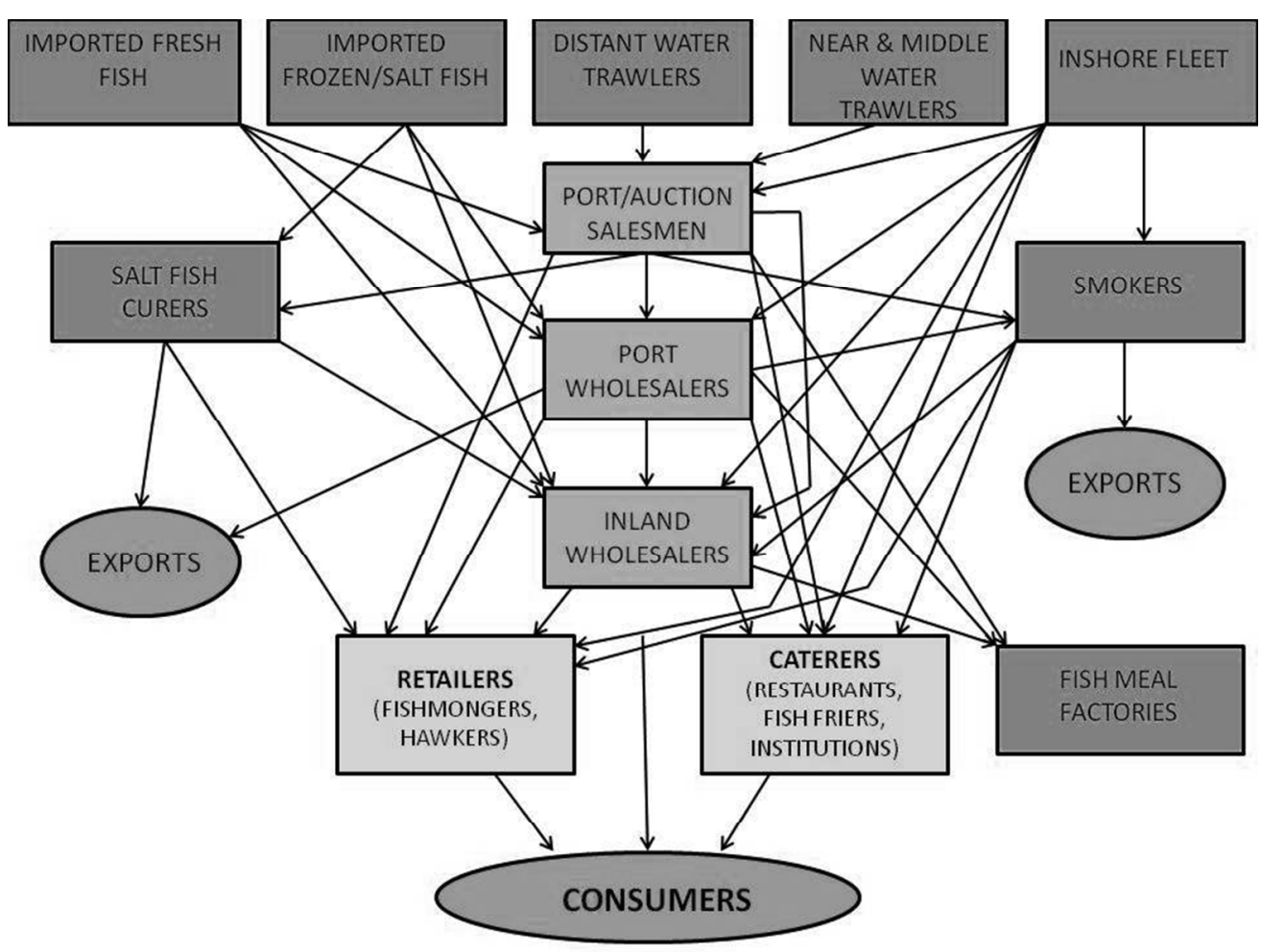

Source: National Archives, MAF 209/709, Cabinet Memorandum by the Secretary of State for Scotland, Minister of Agriculture and Fisheries and the Minister of Food, 19 Jun 1950.

$$
254 \times 190 \mathrm{~mm}(96 \times 96 \mathrm{DPI})
$$


Tables

Table 1

Distribution of Deep-Sea Trawlers, 1951

\begin{tabular}{|c|c|c|c|c|}
\hline Port & $\begin{array}{l}\text { Near Water } \\
\left(70-129^{\prime}\right)\end{array}$ & $\begin{array}{l}\text { Middle Water } \\
\left(130-140^{\prime}\right)\end{array}$ & $\begin{array}{l}\text { Distant water } \\
\text { (140' and over) }\end{array}$ & Total \\
\hline North Shields & 41 & & & 41 \\
\hline Hartlepool & 6 & & & 6 \\
\hline Scarborough & 3 & & & 3 \\
\hline Hull & 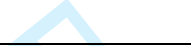 & 4 & 163 & 167 \\
\hline Grimsby & 139 & 6 & 91 & 236 \\
\hline Lowestoft & 120 & & & 120 \\
\hline Yarmouth & 10 & & & 10 \\
\hline Ramsgate & 2 & & & 2 \\
\hline Poole & 1 & & & 1 \\
\hline Brixham & 8 & & & 8 \\
\hline Newlyn & 5 & & & 5 \\
\hline Plymouth & 4 & 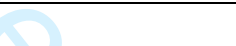 & & 4 \\
\hline Cardiff & 2 & 8 & & 10 \\
\hline Swansea & 7 & 3 & 3 & 13 \\
\hline Milford Haven & 71 & 9 & 8 & 88 \\
\hline Fleetwood & 80 & 2 & 23 & 125 \\
\hline Aberdeen & 199 & 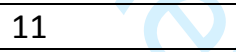 & 3 & 213 \\
\hline Montrose & 3 & 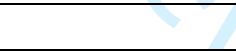 & & 3 \\
\hline \multirow[t]{2}{*}{ Leith } & 39 & 14 & 1 & 54 \\
\hline & 740 & 77 & 292 & 1,109 \\
\hline
\end{tabular}

Source: White Fish Authority, First Annual Report and Accounts for the period ended $31^{\text {st }}$ March 1952. London: White Fish Authority, 1952, 24. 
Table 2

Ownership of Trawlers at selected Major Ports, 1934

\begin{tabular}{|c|c|c|c|c|c|c|c|c|}
\hline \multirow{2}{*}{$\begin{array}{l}\text { No. } \\
\text { Vessels } \\
\text { per firm }\end{array}$} & \multirow{2}{*}{$\begin{array}{l}\text { No. } \\
\text { firms }\end{array}$} & \multirow{2}{*}{$\begin{array}{l}\text { No. } \\
\text { vessels }\end{array}$} & \multicolumn{6}{|c|}{ Percentage of Vessels in each class of ownership } \\
\hline & & & Total & Hull & Grimsby & Aberdeen & Fleetwood & $\begin{array}{l}\text { Milford } \\
\text { Haven }\end{array}$ \\
\hline Under 5 & 206 & 352 & 28 & 11 & 25 & 41 & 31 & 56 \\
\hline 5 to 9 & 39 & 240 & 19 & 15 & 17 & 28 & 20 & 13 \\
\hline 10 to 19 & 26 & 326 & 25 & 22 & 25 & 22 & 36 & 31 \\
\hline Over 19 & 12 & 362 & 28 & 52 & 33 & 9 & 13 & 0 \\
\hline Totals & 283 & 1,280 & 100 & 100 & 100 & 100 & 100 & 100 \\
\hline
\end{tabular}

Source: Great Britain, Sea Fish Commission, Second Report: The White Fish Industry. London: HMSO, 1936, 20. 
Table 3

Average Net Profit of Trawlers at Selected Ports, 1946-9, in Pence per Stone (14lb)

\begin{tabular}{|l|l|l|l|}
\hline & $\mathbf{1 9 4 6 / 7}$ & $\mathbf{1 9 4 7 / 8}$ & $\mathbf{1 9 4 8 / 9}$ \\
\hline Distant Water & & & \\
\hline Hull & 23.03 & 17.68 & 12.46 \\
\hline Grimsby & 18.74 & 12.38 & 9.05 \\
\hline Near and Middle Water & & & \\
\hline Grimsby (middle water) & 5.13 & 4.11 & -3.30 \\
\hline Grimsby (near water) & 2.90 & -8.01 & -4.22 \\
\hline Fleetwood & 10.66 & 9.54 & 6.61 \\
\hline North Shields & 14.30 & 7.37 & -4.85 \\
\hline Aberdeen & 11.29 & -6.57 & -10.96 \\
\hline Milford Haven & 6.75 & -2.65 & -7.00 \\
\hline Swansea & 9.59 & 1.84 & -10.17 \\
\hline
\end{tabular}

Source: TNA, MAF 209/751. White Fish Industry: Short Term Remedies. Report of Official Committee. 
'To Save the Industry from Complete Ruin': ${ }^{1}$ Crisis and Response in British Fishing 1945-1951

\begin{abstract}
Fishing is a small, complex and fragmented industry, which arguably exerts political significance disproportionate to its size. This article traces the prolonged period of depression which affected British deep-sea fishing between the wars, and then a more virulent crisis which erupted in the postwar years. It explores how the industry proved unable to respond effectively, requiring intervention from government which followed a similar pattern to that elsewhere in the economy, albeit tailored to the industry's peculiar circumstances and idiosyncratic nature.
\end{abstract}

\title{
Keywords
}

Fisheries, Labour, productivity, crisis, reorganisation, industrial policy

Fishing is an idiosyncratic industry. It is the only primary producer that involves harvesting wild creatures. Defined broadly to encompass marketing and distribution, as it is here, it also contains elements of secondary processing, and tertiary marketing and sales. It is thus a complex and multifaceted business, and geographically highly dispersed one, with units scattered around much of the country. It is also a small one, which in part is why it has received relatively little attention from economic and business historians, and even some maritime historians have tended to overlook it, or to treat it as unimportant. Studies of its twentieth-century history tend to focus either on the labour history of the catching sector or on the science and politics of overfishing and attempts to ameliorate it, telling a familiar story of increasingly circumscribed access to fishing grounds leading to the collapse of the distant-water sector in the 1970s. ${ }^{2}$ This leaves important areas unexplored, including many key aspects of the business history of the industry. Among these is the crisis which enveloped the deep-sea fishing industry in the years after World War II, a crisis which came close to forcing the lay-up of most of the trawler fleet and cutting off much of the nation's fish supply almost overnight. Despite its seriousness, and despite the fact that government responded by putting in place two key planks of fisheries policy which remain in place, the crisis is virtually unknown. It is not mentioned even in the most comprehensive history of the deep-sea fisheries, ${ }^{3}$ and even some major participants in the industry in the ensuing years are only dimly aware of it. ${ }^{4}$

This article examines the causes, course and effects of that crisis. It first provides an outline of the deep-sea fishing industry between the wars, and explains how the post-war crisis was rooted in problems that had begun to emerge during the 1920s. It also highlights, by way of background, some of the responses on the part of industry and government during the 1930s, arguing that the industry was too fragmented to address its structural weaknesses and required intervention from outside, although this was fairly limited. It then moves on to trace the debates over intervention which resurfaced in the years after World War II, before examining the renewed and much more serious crisis which engulfed the industry in 1949, the renewed inability of much of the industry to respond and the more aggressive intervention from central government. It concludes with a brief outline of the legacy of those years, and of how policy initiatives taken then endure in modified form to the present day. 


\section{The Deep-Sea Fishing Industry, 1921-1945}

The British deep-sea fishing industry experienced rapid growth from the 1840s to the outbreak of World War I. Between the wars, and after, it consisted of three sectors, defined by the size of the trawlers (which by then they all were, long-lining being largely defunct) used and the grounds they fished. Deep-sea fishing vessels were defined officially as those over $70^{\prime}$ in length. Within this, vessels of 70-129' were termed 'near water,' and fished primarily for cod, haddock and other demersal fish in the North Sea, English Channel, Western Approaches and Irish Sea. Most were steam trawlers, although a dwindling number of sailing 'smacks' continued to trawl for high-value species, especially soles, from Lowestoft and Brixham until 1939, whilst internal combustion engines began to come into use during the 1930s. ' 'Middle water' trawlers of 130-139' fished around the Faroe Islands, Rockall, the northern North Sea, and in summer off southern Iceland. 'Distant water' trawlers of over 140' fished Icelandic grounds, catching mainly cod and haddock, and from the 1920s the North Cape of Norway, Bear Island, Spitsbergen, the Barents Sea and the coasts of Greenland and Newfoundland. ${ }^{6}$ The distribution of these vessels by port is given in Table 1.

[Table 1 here]

These figures pertain to 1951, as similar figures for the interwar period are unavailable. However, the distribution of the fleet was roughly similar, although the total number of vessels was greater. ${ }^{7}$

Many of the sailing smacks which dominated the industry until the 1880s had been owned by their skippers, and a few owner-skippers remained in the inter-war period, operating usually elderly near-water steam trawlers at Milford Haven and Aberdeen, and sailing trawlers at Lowestoft and Brixham. ${ }^{8}$ The majority of vessels were owned by limited companies, but most of these were small concerns, as Table 2 indicates.

[Table 2 here]

Small the trawler firms may have been, but they were still much larger than most of the firms on the distributive side of the industry, where the majority of wholesalers both at the ports and the inland markets were very small concerns. In 1934, the average Grimsby wholesale merchant handled just $4,666 \mathrm{cwt}$ of fish, worth only $£ 5,500$. Many were one-man businesses, often financially precarious and short-lived. ${ }^{9} \quad$ Most processing firms, too, were small-scale operations, frequently undercapitalised and operating from cramped and insanitary premises. ${ }^{10}$ The supply chain as a whole was very fragmented, as Figure 1 indicates.

Figure 1

The Fish Distribution Chain

[figure 1 here]

Fish therefore could pass through the hands of four or more concerns, acquiring a mark-up at every stage, until by the time it reached the consumer its price was nearly double that which the wholesale merchant had paid to the trawler owner, whilst it was often none too fresh. ${ }^{11}$ 

jockeyed for position against one another, the three parts of the catching sector had differing priorities and problems, and the interests of catchers, wholesalers, retailers and processors diverged sharply and sometimes acrimoniously. This made it difficult for the industry to represent its collective interests to government and to powerful bodies such as the railway companies, upon which it depended for most long-distance transport. ${ }^{13}$ It also ensured that 'unity of outlook and loyalty to an agreed course of action' were very difficult to achieve. ${ }^{14}$

Such structural issues had mattered little in the years of steady growth before 1914, but became serious during the interwar period. Wages and costs had been driven up during World War I and fell but slowly afterwards, whereas fish prices peaked in 1919, and then entered a declining trend which lasted almost until the end of the 1930s. ${ }^{15}$ This squeezed profits at all levels of the industry. Small and undercapitalised near- and middle-water trawler firms were unable to invest in new vessels, so the fleet became increasingly elderly. By 1934, 88 per cent of the fleet at the major ports, Hull excepted, were more than fifteen years old and a third had been built before World War I. ${ }^{16}$ Many of these were operating in the North Sea, in which the problem of overfishing, and consequent low returns to catchers, had first been highlighted in the late nineteenth century and was increasingly serious by the $1930 \mathrm{~s}^{17}$ Throughout the period, seagoing employment and the number of vessels fell, and the legacy of outdated and unprofitable vessels persisted until well after World War II.

On the distributive side the number of wholesale merchants increased. Wholesaling businesses required minimal capital to establish, and it was therefore an easy business for someone with some knowledge of the fish market and the ability to obtain a little credit to enter. Many of the new firms were founded by former employees of established ones. As their numbers grew, their average turnover fell. By 1934 the majority of wholesalers were making profits on turnover of less than one per cent, and at Grimsby, in particular, the average merchant was reckoned to be operating at a loss. As firms struggled to survive suspicions of sharp practice, such as the 'topping' inferior fish with a layer of high-quality fish to boost the price, and the formation of 'rings' to drive up prices, multiplied. Such activities tarnished the reputation of the industry and its products. ${ }^{18}$

Despite these problems, national landings went up sharply because of the rapid development of distant-water trawling, which by 1930 had driven white fish landings to twentyseven per cent above their 1913 level. ${ }^{19}$ British fishing vessels had worked grounds around Iceland since the 1890s, but the interwar period saw a major move into waters further north, with a new generation of big trawlers, the majority owned and operated from Hull, which was exclusively a distant-water port after 1936, opening up grounds around Bear Island, Spitsbergen and the Barents Sea. ${ }^{20}$ Catches from these grounds were very large, and although the fish was often of indifferent quality, it found a ready market through the expanding fish-and-chip shop trade. Distant-water fishing was therefore profitable at a time when much of the rest of the industry was struggling, and Hull presented 'air of enterprise and confidence' that contrasted sharply with the stagnation evident elsewhere. The industry at Hull was able to do this because trawler firms were fewer and larger, and therefore better able to invest in new vessels, and, because they were all distant-water operators, shared the same interests and priorities. In 1934 half of the Hull fleet was less than ten years old. Wholesale merchants in Hull, too, were on average much larger and more profitable than at the other major ports. ${ }^{21}$ Trawler owners were able to introduce a voluntary scheme to prevent market gluts by restricting landings from northern waters in the summer months, and also a 
minimum price agreement and a scheme whereby fish was filleted before sale and the resulting offal processed in a meal and oil plant owned by a consortium of vessel owners. ${ }^{22}$ This was not achieved without some friction, notably between trawler owners and wholesalers over the minimum price scheme, to which the latter were strongly opposed, ${ }^{23}$ but nevertheless Hull demonstrated the advantages of homogeneity and concentration, which made possible the 'unity of outlook and loyalty to an agreed course of action' so notably absent elsewhere.

Hull's success, however, was alleged by others to have worsened the plight of the rest of the catching sector, as heavy landings from distant waters dragged down prices across the board. ${ }^{24}$ Hull owners disputed this, arguing that they served separate markets and that their catches had no effect on prices for higher-quality fish from the home grounds. ${ }^{25}$ It does seem, however, that heavy distant-water landings fed into the general trend of falling wholesale prices, worsened by the onset of the global economic depression in 1930. By 1931 the government's Economic Advisory Committee could write that:

We are ... confronted with a situation in which the fish which the British trawling industry can market is substantially below its productive capacity. ${ }^{26}$

The situation was exacerbated by rising imports of fresh fish. On the recommendation of the Economic Advisory Committee the Sea Fishing Industry Act of 1932 restricted imports to a total of 13/4 million hundredweight, a ten per cent reduction on the 1930-2 level. That same Act empowered the Minister of Agriculture to impose restrictions on landings, and an Order was immediately made prohibiting landings from some of the distant-water grounds in the summer months, giving statutory force to the voluntary scheme previously agreed by Hull owners. ${ }^{27}$

Restrictions on imports, ameliorated by bilateral deals with selected countries, were in line with the general thrust of British government policy during the depression. ${ }^{28}$ The precedent they set was invoked repeatedly after the war when imports once again became controversial. Typical, too, were other measures taken to bolster the industry. Their problems were in some respects similar to those afflicting agriculture, and so were the solutions, which aimed at eliminating overcapacity, stabilising markets, bolstering demand and encouraging effective self-government. Under the Agricultural Marketing Acts, marketing and minimum-price schemes financed by levies were set up by new bodies such as the Milk and Potato Marketing Boards. ${ }^{29}$ The first application of this thinking to fisheries actually addressed the herring fishing industry - not part of the deep-sea sector - for which the Herring Industry Board was set up in 1935 to oversee a programme of grants and loans to encourage investment in more efficient vessels, research and development of new catching and processing technologies, and improvements in marketing. ${ }^{30}$ The Herring Industry Board, which survived until 1981, set the precedent for intervention in the deep-sea fisheries, which came in the form of the White Fish Commission, established under the Sea Fisheries Act of $1938 .^{31}$ It was tasked with conducting a comprehensive review of the industry, in the wake of which it would introduce regulations on handling, grading and quality control, and develop marketing schemes similar to those already in force for various agricultural products. ${ }^{32}$ It was also empowered to enforce registration of firms and individuals engaged in the fish trades, and to co-ordinate research and development work. This was not just in line with British government policy: in many other European countries governments took broadly similar measures to protect and stabilise their fishing industries. $^{33}$ 


\section{Reconstruction, Prosperity and Slump, 1945-50}

The Labour government that came to power in July 1945 faced unprecedented economic problems. To the dislocation and physical damage caused by the war were added vast debts which necessitated loans from America and engendered recurrent balance of payments crises, and also severe shortages of fuel, food and other goods. ${ }^{41}$ Alongside these formidable and well known difficulties, fishing hardly loomed large on the political agenda. It was a small industry, widely dispersed around the country and lacking in organised political representation, and although some fishing-port constituencies did return knowledgeable and able Members of Parliament they came from across the party political spectrum and rarely acted in concert. ${ }^{42}$ Yet fishing did matter. Firstly, it was a major employer in parts of the country where alternative employment was at best scarce, at a time when the experience of mass unemployment was fresh in policymakers' minds. Secondly, it was strategically important, as a provider of food and as a source of vessels and highly skilled labour 
for the Royal Navy to draw upon in wartime. Finally, the activities of fishing vessels in the waters of other states gave it an international dimension absent from other industries of comparable size. From 1948 onwards, the industry began to assume greater prominence in the minds of politicians, as the problems of the 1930s re-emerged in more virulent form, and were joined by new issues thrown up by the changed geopolitical climate.

The Duncan Commission had highlighted inefficiencies in the supply chain, an aged fishing fleet and overproduction. The first of these was in abeyance, since wartime distribution arrangements remained in force, but the second had been worsened by the war because many of the newest vessels had been lost on naval service. The fleet had already begun to expand again, however, as the Admiralty began to demobilise vessels and pass them back to their owners, a process which had begun as early as 1943 and ensured that the major east coast ports were functioning again by the time the war in Europe ended. Some firms also went on a building spree, such as Hull-based Kingston Steam Trawling, which embarked upon a programme of updating its fleet by selling off old vessels and purchasing new tonnage. ${ }^{43}$ Between 1945 and 1948 the numbers of trawlers active at Hull rose from 99 to 149, at Grimsby from 168 to 254 and at Fleetwood from 31 to 127 , although there was a small drop at Lowestoft, from 66 to $62 .{ }^{44}$ The pre-war pattern, of nearand middle-water vessels dispersed around a variety of ports whilst the Humber and Fleetwood dominated the distant-water sector, quickly re-emerged, as the figures in Table 2 show.

During 1949 alone, 32 new distant-water trawlers came into operation. Many of these were deployed on the northern grounds, which had been little exploited for six years and now yielded very high catches, and they also made slightly longer trips than before the war. ${ }^{45}$ Accordingly, by late 1946 some on the distributive side of the industry were already voicing concerns about a recurrence of the overproduction problem. ${ }^{46}$ Total fish supplies in 1947-9 were over the million-ton mark, as opposed to 800,000 before the war, primarily because of the resurgence of distant-water fishing. Moreover, costs were rising again. Kingston Steam Trawling noted in 1947 that the cost of new vessels had risen from $£ 83,000$ to $£ 99,000$, and by 1949 they had reached $£ 125,000 .{ }^{47}$ Labour costs were rising, the coal shortages of 1947-8 drove up the fuel bill, and across the industry there was a 'persistent increase in prices of stores and supplies. ${ }^{48}$ This began to squeeze the incomes of trawler firms, especially those deploying near- and middle-water vessels on the North Sea grounds where, even by late 1946, signs of overfishing were re-emerging. Yields began to drop off after a post-war high, and much of the catch was small and of low value. ${ }^{49}$ Moreover, the pre-war import controls had not been reinstated, although a ten per cent ad valorum duty was in force, and imports were well above their pre-war levels. Britain imported 6,029,808cwt of fish in 1947 and 4,997,366 the following year, as opposed to a 1938 figure of $3,558,000 .^{50}$

All of this could have spelled a rapid return to the depression of the 1930s, but two factors stabilised the situation for the time being. Firstly, the general economic climate of the late 1940s helped to shore up demand. Substitute foodstuffs, especially poultry and red meat, were still rationed, and indeed the meat ration was cut to below wartime levels in 1946. Moreover, although fish had not been rationed, shortages had served to limit consumption during the war. For both of these reasons there was sufficient demand from consumers to absorb the increase in supplies in the immediate post-war years. ${ }^{51}$ Meanwhile, for the time being much of the wartime distribution structure remained in place. Price controls continued, as did flat-rate transport and the system of merchants' allocations. This was slightly modified in 1947 and allocations were granted to some new entrants, drawing protests from existing merchants whose allocations would be encroached upon. During 1947-8, too, the zoning scheme was amended and some of the controls on which 
inland wholesalers port merchants could supply were withdrawn. ${ }^{52}$ These were only slight relaxations, however, and the wartime distribution scheme remained essentially intact.

By 1948 the climate was changing. Controls, which were felt to have outlived their usefulness, were beginning to be removed in various sectors of the economy, culminating in Harold Wilson's 'bonfire of the controls' at the Board of Trade. ${ }^{53}$ The government's attitude towards sectors such as fishing was becoming clearer too. Minister of Food John Strachey explained to Hull merchants in 1947 that it intended 'to create open competition in trades which could not be nationalised in order to safeguard the public against exploitation. ${ }^{54}$ Such thinking underlay a broader attack on monopolies and restrictive practices. ${ }^{55}$ All of this pointed in the direction of decontrol in the fish trades, and during 1948 pressure for this began to build up, especially from the BTF. ${ }^{56}$ Consideration was given to a staged process, controls on retail prices remaining temporarily whilst those on prices further up the supply chain were removed, but merchants opposed this on the grounds that it would create chaos and encourage the black market, an argument the government evidently accepted. ${ }^{57}$ The tide was now flowing in the direction of complete decontrol, and during 1948-9 expectation built up that 'controls would be off altogether. ${ }^{58}$

As decontrol came into view the first signs of serious trouble began to emerge. The first issue was the connected problems of overfishing and fishery limits. Neither was new, but the latter was beginning to assume a more intractable form, and bore especially hard on the distant-water fleet. Britain had signed an international convention on overfishing in the North Sea in 1946, in an attempt to prevent a recurrence of pre-war overfishing, and two years later the White Fish and Herring Industries Act of $1948^{59}$ gave the Minister of Agriculture and Fisheries the power to impose a licensing scheme on vessels working the North Sea grounds. The convention did not come into force until 1954, however, and even then it was largely ineffectual. ${ }^{60}$ In any case, British attempts to combat overfishing aimed at securing multilateral agreements controlling fishing effort on the High Seas, whereas by this time, in the wake of President Truman's 1945 proclamation on the United States' right to control the resources of the continental shelf, others were more focused on unilateral extensions of fishery limits. ${ }^{61}$ Iceland posed a particular problem in this respect. Having gained independence from Denmark in 1944, in 1949 the Icelandic government gave two years' notice of intention to abrogate the 1901 Anglo-Danish treaty which fixed Iceland's territorial waters

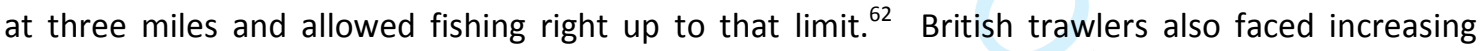
restrictions on their activities off the coasts of Norway and the USSR, about which the British government could do little. ${ }^{63}$

Nor could much be done about the catching sector's costs. For much of 1948 fish sold in the shops at or near to the controlled maximum price, ${ }^{64}$ but the rising cost of catching, especially in near waters, meant that this was no longer enough to return a profit. Table 3 presents the results of a Ministry of Food investigation of the costs and revenues of various trawlers between 1946 and 1949.

[Table 3 here]

As Table 3 shows, generally healthy profits in 1946-7 dwindled rapidly until by 1948-9 most nearand middle-water vessels were making serious losses. Nationally, of 837 such vessels, no fewer than 637 had been built before 1921. Many were worn out and expensive to maintain, and as coal burners they were vulnerable to the general increase in fuel costs. They also offered dismal accommodation and working conditions, which were held to deter young men from entering the industry at a time of full employment. ${ }^{65}$ There was little hope of replacing them in the foreseeable 
future. To tide them over, the Ministry of Food began paying a subsidy of ten pence per stone on fish landed from near- and middle-water grounds from November 1948, joining an international trend towards subsidising fishing which had accelerated between the wars but which Britain had not joined. ${ }^{66}$ This was just about sufficient to restore profitability, but few can have been under any illusions that it would resolve the industry's difficulties.

An already precarious situation took a sharp turn for the worse a year later, when predictions of a renewed overproduction problem were suddenly vindicated, and the sellers' market of the immediate post-war years came to an abrupt halt. As the general food shortages abated and rationing, especially of meat, was eased, consumers looked upon fish with increasing disfavour and consumption began to fall. ${ }^{67}$ Price controls had encouraged catchers to aim for quantity rather than quality, and much distant-water fish, especially, was stale. This in turn dragged down the price of better quality fish. ${ }^{68}$ As The Economist put it, fish embodied 'all the least attractive features of austerity,' and consumers were 'sick, tired and fed up' with it. ${ }^{69}$ Wholesale prices suddenly collapsed in November 1949. A year earlier, a stone of cod at Grimsby had sold for $6 \mathrm{~s} 6 \mathrm{~d}$, but this now fell to $3 \mathrm{~s} 7 \mathrm{~d}$. Nationally, cod prices fell from $5 \mathrm{~s} 10 \mathrm{~d}$ per stone to $3 \mathrm{~s} 7 \mathrm{~d}^{70}{ }^{70}$ This plunged the nearand middle-water sectors back into crisis, and the distant-water fleet into 'crippling' losses. ${ }^{71}$ It was apparent to all concerned that there was no easy solution, and that the 1948 subsidy scheme, which had helped to hold the line up to this point, would not prevent the situation worsening. Equally, however, it was widely accepted by now that controls were part of the problem. Not only did they encourage catchers to prioritise quantity over quality, but by assigning quota to each merchant they destroyed competition and removed any incentive to improve efficiency. In short, 'trade channels became stereotyped. ${ }^{72}$ This hastened the move towards decontrol, in the hope that it would encourage catchers to land better quality and thus more valuable fish, which should help to restore profitability. ${ }^{73}$

Decontrol came on Saturday 15 April 1950. At the same time, the Ministry of Food subsidy to near- and middle-water catchers ended, and also the flat rate transport scheme and the remaining licensing restrictions on wholesalers, the latter against the advice of the trade, which was well aware that the wholesaling business remained all too easy for the unscrupulous and unsuitable to enter. ${ }^{74}$ The result was chaos. The number of wholesale merchants on the fish market in Hull went up from 400 to 600 literally overnight, and similar increases occurred at other ports. Amid 'frenzied bidding' at the auctions, prices rocketed. Two days later, on the Monday, this was 'sharply corrected. ${ }^{75}$ Wholesalers at the inland markets refused to purchase fish at such prices, and consumer resistance also emerged. As Barbara Castle put it in the House of Commons a fortnight later, 'the Housewife is becoming tired of these conspiracies against her purse. ${ }^{76}$ Demand ebbed away, and the spike in prices gave way to a renewed fall. The price of distant-water fish dropped from an average of $4 \mathrm{~s} 6 \mathrm{~d}$ per stone in the week ending 22 April 1950 to 3s 1d by 13 May, and distant-water trawlers' average earnings dwindled from $f 173$ per day at sea to just $f 115$, against an estimated cost of $£ 200$ per day to keep a big trawler at sea. Once again, plummeting prices for distant-water fish served to drag down prices across the board. ${ }^{77}$

In the face of such losses, owners began tying up their vessels. Thirty-nine trawlers were laid up at Grimsby by the end of April, and eighteen at Lowestoft a fortnight later. ${ }^{78}$ Nationally, by the last week of May, 170 of the estimated national fleet of 1,142 trawlers were laid up. The position was especially serious at Milford Haven, where nearly a third of the fleet lay idle, but Aberdeen, Grimsby, Fleetwood and Hull had also been badly hit. ${ }^{79}$ At a stormy meeting on 18 May, the BTF decided against ordering a complete lay-up of its members' vessels, mainly because such a 
move would cost the industry dear in terms of goodwill, ${ }^{80}$ but the position remained highly unstable, and on 19 June Federation President Jack Croft Baker again reported to the Ministry of Agriculture and Fisheries that he had 'had great difficulty in restraining the meeting from deciding to lay up all trawlers' forthwith. ${ }^{81}$ Croft Baker may have been exaggerating, and certainly some within the Ministry felt that a 'complete stoppage' was unlikely, not least because the BTF did not speak for the whole sector. ${ }^{82}$ Hull trawler owners had left the Federation before the war and only rejoined in 1950, but thereafter all were members, whereas in early 1951 only 36 of the 113 trawlers at Lowestoft were covered. ${ }^{83}$ Nor did the BTF cover Scotland, whose catchers were represented by the Scottish Trawlers' Federation. BTF members or not, however, trawlers were losing money and increasing numbers were being laid up, and whilst a complete stoppage was unlikely it remained an alarming possibility.

How serious would such a stoppage have been? The first result would have been to cut much of the nation's fish supply off, almost literally overnight. Given that in 1949 the deep-sea trawler fleet landed 90 per cent of the British catch, if only half of the fleet had tied up the effect on supplies would have been profound. ${ }^{84}$ There would doubtless have been a surge in imports to compensate, which would have helped to support processors and distributors but would have depressed the catchers' position further. Nor would it have been sufficient to prevent prices soaring. Even though wholesale prices had plummeted this had not yet been reflected in the shops, where fish continued to sell at around its former control prices, and there was now nothing to prevent it rising further. This in turn could lead to a demand for the reintroduction of price controls, something the government was keen to avoid. ${ }^{85}$ Certainly, shortages and high prices would have been unpopular. It is telling that two years later the British Housewives' League and Cheap Food League, along with The People newspaper, mounted a major campaign against renewed landing restrictions by distant-water trawling firms. ${ }^{86}$ What the government and civil servants professed to fear most, however, was unemployment. By late May 3,500 men were already out of work and thousands more would follow in the event of a mass lay-up, not only among fishermen themselves, but in ancillary industries such as trawler maintenance and supplies, and in processing firms starved of fish. ${ }^{87}$ This would have caused severe hardship in the fishing ports, where alternative employment was not easily found, and civil disturbances could follow. ${ }^{88}$

One thing that was certain was that the crisis was becoming an increasing embarrassment to the government. Conservative MPs such as Richard Law had already used it to mock Labour's 'claim to have provided full employment,' and similar sentiments were being voiced behind closed doors. ${ }^{89}$ For all of these reasons, even though it affected a small and dispersed industry, the crisis was greeted with some alarm. As the Fisheries Secretary at the Ministry of Agriculture and Fisheries, Peter Dunn, put it, 'the situation is deteriorating so rapidly and is likely to become [so] acutely embarrassing to government that some announcement on policy cannot long be delayed. ${ }^{90}$

\section{Responses}

The deep-sea fishing industry in the 1940s was no less fragmented, fractious and difficult to coordinate than it had been between the wars. The distant-water trawling sector, relatively small and concentrated in a few ports, did manage to develop a scheme to combat overproduction and shore up prices, but even here agreement from all players was impossible to secure. For the industry as a whole the attitude of government, shared by civil servants in all of the relevant Ministries, was once again that it was incapable of resolving its own problems and required decisive intervention. 
The first reaction of almost the entire catching sector, and the one thing on which they all agreed, was to blame the crisis on imports, pre-war restrictions on which had not been re-imposed. As early as June 1946 a drop in wholesale prices had led trawler crews or officers at Hull, Grimsby, Aberdeen, North Shields and Lowestoft, who were paid partly by share of profits, to refuse to put to sea. ${ }^{91}$ Crews blamed imports, a cry taken up by trawler owners, who complained that the government would do nothing to restrict them despite the 'tremendous harm' being done to the domestic industry. ${ }^{92}$ Agitation became fiercer during 1948 and reached a crescendo in 1949-50 as their financial position crumbled. In May 1950 the Lowestoft Fishing Vessel Owners Association sent a telegram to the Ministry and local MPs stating that their situation was 'becoming critical mainly due to foreign imports,' and stressing the need for 'immediate government action to prevent collapse and general unemployment. ${ }^{93}$ This was followed a fortnight later by a deputation from the BTF, which demanded both a subsidy to see the industry through the immediate crisis, and restriction of imports to 1938 levels. ${ }^{94}$ Trawler owners at all major ports were agreed that, without import restrictions, their future looked bleak.

If the trawler owners and crews had nailed their colours to the protectionist mast, however, others were not so sure. Some wholesalers felt that the lack of import restrictions was unfair to the domestic fleet, and in Lowestoft the merchants broadly supported the local trawler firms upon whose supplies they depended. On the Humber, however, trawler owners' proposals that wholesalers should refrain from buying fish landed by foreign vessels met with support only from Grimsby merchants on condition that their counterparts in Hull agreed to do likewise. This, after some debate, they did not agree to, mainly because many of them were selling fish landed by foreign vessels, which continued to come to British ports despite facing hostility and sometimes obstruction from shoreside workers and trawlermen. ${ }^{95}$ Moreover, wartime cooperation between catchers and merchants was starting to revert to the antagonism of the 1930s. In the largest port, Hull, some trawler owners, via their interests in the local ice-manufacturing firm, attempted to secure a merchants' licence and allocation, and thus enter the distributive side of the industry, something the established wholesalers were keen to resist. ${ }^{96}$ At least one scheme to improve the quality and marketing of fish at the port had already collapsed due to lack of cooperation. ${ }^{97}$ The climate of mutual suspicion and occasional recriminations between catchers and distributors did not make the industry any easier to deal with, and nor did the fact that the distant-water sector's problems were bound up with the international political and economic situation.

The distant-water sector, though, at least retained its longstanding advantage of being small, concentrated and cohesive, and this was the one part of the industry that managed a partial solution to its difficulties. From the late 1940s owners had recognised that the overproduction problem 1930s was likely to recur at some point, and began working on a plan to restrict catching capacity and limit landings from northern waters. By March 1950 distant-water firms at Hull and Grimsby had prepared a draft scheme. ${ }^{98}$ Negotiations were hastened by the crisis then reaching its height, and the scheme was signed by most distant-water firms on the Humber in July that year. Even here agreement was not universal, however, for firms representing eleven per cent of the two ports' distant-water capacity declined to join what was by then termed the Distant Water Vessels' Development Scheme. ${ }^{99}$ Moreover, the only other significant distant-water port, Fleetwood, had not been consulted and was presented with it as a fait accompli, which the Humber firms declined to modify to accommodate the Lancashire port's circumstances. ${ }^{100}$ This was done later, however, when a revised Development Scheme was worked up in less haste, and within a few years it embraced the entire distant-water sector in England, although the few distant-water vessels in Scotland remained 
outside it. ${ }^{101}$ It allowed for the lay-up of up to 25 per cent of capacity on a seasonal basis, restrictions on the building and modification of distant-water trawlers, and a system of vessel quotas to prevent excessive landings. ${ }^{102}$

The Development Scheme did not immediately restore the distant-water sector to profit, and investigations in 1952 and 1953 suggested that it was still losing money. ${ }^{103}$ Nevertheless, owners were confident that in the longer term it would solve their problems, and it does appear to have brought a measure of much-needed stability. ${ }^{104}$ Yet the distant-water sector, although it contributed more than two-thirds of British white fish landings, ${ }^{105}$ was but one part of the catching sector. Resolving the immediate and longer-term problems afflicting dozens of smaller firms that made up the near- and middle-water sectors, curing the inefficiencies in the supply chain and creating some order out of the highly fragmented industry as a whole were tasks of a different order of magnitude. They were tasks that, in the opinion of many in government and some in the industry itself, required decisive intervention from outside. ${ }^{106}$

The task of formulating a plan to intervene fell primarily to civil servants in the Ministry of Agriculture and Fisheries, who greeted the crisis with some alarm, but also with exasperation. As one remarked, at decontrol the industry had 'once again demonstrated its utter irresponsibility and absence of discipline. ${ }^{107}$ Nevertheless, they had to fight on two fronts. Firstly, urgent action was needed to stem the catchers' losses and halt the lay-ups, and secondly, they needed to formulate a plan to put the industry back on its feet in the longer term.

The question of how to stave off collapse in the catching sector was debated intensely during early 1950. Calls for import restrictions were given short shrift. At an interdepartmental conference in May 1950 representatives from various departments pointed out that an industry which catered for 85 per cent of the home market could not, prima facie, be considered threatened by imports, and that they were in any case declining. Indeed, as a representative of the Board of Trade commented, imports had 'remarkably little to do with the matter.' Instead, criticism was levelled at the British industry for waxing fat in the sellers' market of the immediate post-war years and failing to address inefficiencies highlighted by the Duncan Commission, whose report was now fourteen years old. In short, most departments felt that the problems lay at home, and that although import restrictions might provide a little short-term relief, they were not the panacea the trawler owners seemed to think. ${ }^{108}$

In any case, the question of protection opened up wider issues of Britain's international situation. In particular, any attempt to restrict imports would have hurt Iceland badly. Fish and its products accounted for around 90 per cent of Icelandic exports, of which about a third went to Britain. ${ }^{109}$ Trawler owners were well aware of this, which is why they urged government to use the threat of restrictions to deter Iceland from extending her fishery limits. Yet this ignored more fundamental geopolitical difficulties. Iceland was crucial to the Atlantic Alliance and becoming more so as the Cold War began to take shape, and overlaying everything was the possibility that Iceland could throw in its lot with the Communist bloc, with serious implications for the position of the nascent North Atlantic Treaty Organisation in the northern seas. This was why ultimately, despite the aggressive attitude of the industry and some in the civil service, especially Peter Dunn, who felt the Icelanders were 'wholly unreliable as friends,' the Foreign Office's conciliatory view prevailed and Iceland was treated with caution. ${ }^{110}$

Moreover, the international economic climate was shifting fast, away from the protectionism of the 1930s and towards a more liberal, free-trade order. The United States was at the forefront of liberalisation, and the United Kingdom, beset by post-war economic difficulties, had 
little choice but to acquiesce, even though some within the Labour government were unhappy about it. ${ }^{111}$ Among the aims of the Organisation for European Economic Cooperation, founded in 1948, was the promotion of free trade through reduction of tariff barriers and import controls, whilst the year before Britain had been one of the founding signatories of the General Agreement on Trade and Tariffs. Its impact was initially small, but it did make imposing new restrictions politically difficult. ${ }^{112}$ In this climate, restricting fish imports, which would hurt not only Iceland but also Norway and Denmark, and to a lesser extent Belgium and the Netherlands, would create a 'deplorable impression.'113 It would upset much of Europe and the United States, and undermine the UK's wider policy on international trade. The Foreign Office also felt that it risked sparking off a trade war, with potentially even more harmful consequences. ${ }^{114}$ For both of these reasons, although consideration was given behind the scenes to restricting imports, and at one stage the possibility was even discussed with the OEEC, ${ }^{115}$ calls from within the industry and from parliamentary protectionists of left and right ${ }^{116}$ could not be allowed to prevail, and solutions to the fishing industry's crisis had to be sought at home.

If reviving import restrictions was politically impossible, and there was no prospect of a resurgence of demand to push up prices, the only short-term option open was to subsidise the industry until times improved. ${ }^{117}$ This was hotly debated between departments in the early months of 1950. The Treasury held out against a subsidy, arguing that the need for it was unproven. No other department took quite this line, but objections from the Ministry of Food and Board of Trade, among others, were founded on the belief that an open-ended subsidy would simply perpetuate the fisheries' problems, and that any financial assistance would have to come with conditions, and an acceptance of the need for restructuring. ${ }^{118}$ In fact, even those who advocated a subsidy, such as officials from MAF, were agreed that 'some amount of blood-letting was necessary,' but felt that the alternative was the collapse of much of the industry. ${ }^{119}$ They also pointed out that fish was in competition with foods whose production was far more heavily subsidised, and that fishing had received little protection from rising costs and subsidised foreign competition. Moreover, although representatives from the Ministry of Labour had argued that government money would be better spent on creating alternative employment opportunities in the fishing ports, in practice this would be extremely difficult to achieve, so the result of leaving the industry's fortunes to the market would probably be mass unemployment, spiralling retail prices and perhaps unwelcome demands for the reimposition of price controls. ${ }^{120}$ Perhaps inevitably, the result was a compromise; a time-limited subsidy intended to tide the industry over until longer-term remedies to its ailments could be applied from outside.

There was little debate over what form this new intervention should take. Nationalisation of the fishing fleet was never considered, despite some calls from backbench Labour MPs. ${ }^{121}$ Fishing, unlike the industries that were targeted for nationalisation, was not a basic industry providing services to the rest of the economy, and the dozens of firms that comprised it lacked a cadre of professional managers to whom its running could be entrusted. ${ }^{122}$ It therefore fitted ill with Labour's generally technocratic approach to nationalisation. In any case, it was felt that the trawler owners would almost certainly refuse to cooperate, which was probably correct, not least because the industry tended to gravitate towards the Conservative Party. Several trawler firms were regular donors to it, in some cases along with free-market lobby group the Economic League, and regarded the Labour government with suspicion. ${ }^{123}$ Nor was there any realistic prospect of nationalising even part of the plethora of small firms that made up the processing and distributive sides of the industry. Therefore, for all that some trawling firms suspected otherwise, ${ }^{124}$ the government was determined 
that as far as possible fishing would be 'left to the operation of the price mechanism,' and competition would be encouraged to keep prices to the consumer as low as possible. ${ }^{125}$

The government therefore proceeded on the assumption that fishing would remain within the private sector, but that some form of independent body was needed to drive through the necessary restructuring. One obvious option, suggested back in 1947, was to revive the White Fish Commission. ${ }^{126}$ Yet this had been a consultative body, and its powers of compulsion were too limited for the radical reorganisation now deemed necessary. The Commission was therefore officially abandoned and civil servants spent much of 1949 and early 1950 drawing up a successor body with 'dictatorial powers.' 127 Like the Development Councils established in certain other industries in an attempt to drive through modernisation this was not to be a representative body, still less one dominated by Trade Associations representing sectional interests. ${ }^{128}$ Rather, it was to be composed of outsiders whose task was to examine and reform the industry as a whole, albeit in consultation with an advisory council. ${ }^{129}$ In short, it was an organisation very much in line with the Attlee governments' wider commitment to raising productivity and improving efficiency across the private sector, itself a philosophy rooted in the 1930s and consolidated during and after the war. ${ }^{130}$

Provisionally called the White Fish Industry Board, the new body was to be charged with the 'regulation, reorganisation and development of the white fish industry,' which was defined very broadly to encompass all sea fish other than herring, whose production and distribution was still overseen by the Herring Industry Board. What form this reorganisation would take was to be left to the Board to determine after it had investigated the industry. However, it was to have powers to 'secure the merger of trawler owners, processors and wholesale merchants at the ports of landing,' to 'rationalise the marketing and distribution of fish by operating marketing schemes controlled by the Board and not by producers' and 'to operate schemes for regulating catches of fish by British vessels and dealing with landings of foreign caught fish.' It would be entitled to trade in fish and operate processing plant on its own account, and 'to acquire and operate fishing vessels and processing plants.' It would also be empowered to register all participants in the industry, and endowed with powers of entry and inspection of premises and books to ensure compliance. ${ }^{131}$ All of this pointed to fundamental restructuring of the distribution chain, and rationalisation and close regulation of catching. From the outset, however, Ministers quietly assured the BTF that the Board would have no power to purchase companies' shares compulsorily and that its powers to trade in its own right would in practice only be deployed where existing marketing arrangements were inadequate, which would be in small ports and would thus affect mainly the inshore fisheries. ${ }^{132}$

The remainder of the Board's powers were less potentially controversial, and resembled those of the pre-war Commission. It was to be empowered, subject to ministerial approval, to establish national regulations on handling of fish, quality control and minimum price schedules, to develop marketing and publicity campaigns to increase demand for the industry's products, and to establish schemes and bodies to promote exports. It was to act as a coordinating body for publiclyfunded research and development, in collaboration with the Department of Scientific and Industrial Research, which operated the Torry Research Station at Aberdeen and was in the process of setting up a branch laboratory in Hull specialising in fish quality and preservation. ${ }^{133}$ In this respect it fitted into the general trend of expansion in government-funded industrial research in the late 1940s. ${ }^{134}$ Finally, the Board was to act as the conduit for government money flowing to the industry. It would provide grants for training of fishermen and shore-based workers, and it would administer a system of government-funded grants and loans for modernisation and replacement of shore establishments 
and fishing vessels. All of this would be funded partly by the Treasury, and partly by a levy of a penny per stone on all white fish, deducted at the point of first sale. ${ }^{135}$

The process culminated in Clement Attlee's statement to the House of Commons on 4 July 1950, in which he remarked that:

The difficulties of the white fish industry are basic, complex, and of long standing. There is, therefore, no simple solution to them. The view has often been expressed in this House that their difficulties are not likely to be overcome by the industry itself. The Government agree with this view and have decided to promote legislation to set up an Authority with adequate powers to regulate, re-organise and develop the white fish industry.

By this time the Board had been rechristened the White Fish Authority. Its precise powers and functions were still being worked out and would not be made public for some months, until legislation had been prepared. Nevertheless, it was obviously expected to drive through changes at all levels of the industry. As an interim measure the Prime Minister also announced an immediate subsidy scheme, in effect a continuation of the Ministry of Food subsidies from 1948, which would 'secure improvement in the fishing ports meantime and until the White Fish Authority is able to apply long term remedies. ${ }^{, 136}$ This was given effect in the Sea Fish Industry Act, $1951 .{ }^{137}$

By now the distant-water sector had pinned its faith on its own Distant Water Development Scheme, and although it could not avoid being brought within the Authority's remit it was exempted from the subsidies. ${ }^{138}$ The middle- and near-water sectors, with their outdated fleets and track record of unprofitability and stagnation, were more welcoming. F.E. Catchpole, chairman of the Lowestoft Fishing Vessel Owners' Association, probably spoke for many when he thanked the Authority for visiting the port in April 1951 and stated that 'already he had the feeling that they were getting on with the job and would do it well. ${ }^{139}$ The distributive side of the trade was more cautious, and among the Hull merchants in particular there was concern that the Authority might end up being dominated by the trawler owners, and that its 'object seemed to be in direct opposition to ours as they wanted to cut out a lot of dead wood in the Industry.' These fears were reinforced the following year by the omission of a Hull merchant from the White Fish Advisory Council, which had first been established to advise the White Fish Commission and was revived to serve its successor. ${ }^{140}$ Moreover, wholesale merchants nationally felt that the levy to fund it fell unduly heavily upon them, which coloured their view of the Authority from the start. ${ }^{141}$ In Parliamentary circles, with the exception of some right-wing Conservative MPs who thought it was a vehicle for nationalisation by the back door, and some on the left of the Labour Party who thought it should be, the Authority enjoyed cross-party support, and it began its work with a fair political wind. ${ }^{142}$

With the continuation of subsidies and the promise of fundamental reform from the White Fish Authority, the sense of crisis quickly abated during the summer of 1950. Most of the laid-up trawlers were sent back to sea, although some of the oldest went instead to the breakers' yard, leaving the number of near- and middle-water vessels in 1951 slightly lower than in $1949 .{ }^{143}$ The demand for import controls also faded, although it did not disappear entirely. ${ }^{144}$ The situation improved further that winter, from the catchers' point of view at least, when bad weather and consequent shortages of supplies, coupled with another cut in the meat ration, sent prices soaring. This led to renewed calls for the reimposition of price controls, which were taken seriously enough 
to be considered behind the scenes. ${ }^{145}$ However, the distant-water owners responded by suspending the Distant Water Development Scheme and sending all of their vessels to sea, which served to bring prices back down over the next couple of months. ${ }^{146}$ Once again, the sense of crisis faded into the distance.

\section{Legacy and Conclusions}

The period between 1945 and 1951 represented a watershed in relationships between government and the fisheries. Historically, although sections of the industry had long accepted that government had a role to play in securing access to key fishing grounds and policing the behaviour of their users, and at times had advocated greater government action on these fronts, it had generally been very hostile to government 'interference' in how participants conducted their businesses. However, this hostility abated in the depressed circumstances of the 1930s, and the crisis after 1945 fostered a sufficiently strong consensus that reform was needed to quiet most potential opposition to governmental interference in a business that had generally preferred to be left well alone.

On the industry's side, the Distant Water Development Scheme remained in force until it was rendered superfluous by Britain's accession to the European Economic Community in 1973. At this point it was replaced by the Fish Producers' Organisation (FPO). Producer Organisations, under European rules, are voluntary associations of catchers set up to coordinate production and marketing of fish and agricultural products. ${ }^{147}$ The FPO was the first such organisation in Britain. ${ }^{148}$ Initially it was composed primarily of Humber distant-water trawler firms. By then, however, the threat to their main fishing grounds that was already apparent in 1949-50 had become critical, and three years later Icelandic fishing grounds were closed altogether to British trawlers, tipping the distant-water sector into terminal decline. ${ }^{149}$ The FPO exists to this day, although its membership has altered greatly with the disappearance of most of the firms that founded it. The distant-water sector managed to develop reasonably effective responses to the problem of overcapacity in the early 1930s and again in 1950, but never to resolve the problem of access to its own resource base, which was tangentially related but ultimately much more serious.

Between the wars and after 1945, the near- and middle-water sectors, and the distributive side of the industry, were far less capable of acting in concert, and were vulnerable to disastrous losses when the market moved against them. It was the threat of their collapse that provided the impetus for decisive intervention. The interventions of the 1930s were very much in line with those adopted in other struggling industries and aimed at boosting demand and encouraging industrial self-organisation rather than intervening in a very direct manner. In the case of the deep-sea fisheries, however, the White Fish Commission, came too late to have any significant effect before war intervened, if indeed it ever could, which given its limited powers is doubtful. Elements of it resurfaced in 1950, however, in the form of the White Fish Authority, which exemplified a more aggressive form of intervention to reorganise struggling industries not slated for nationalisation. ${ }^{150}$ The Authority commenced its work formally in July 1951 under the chairmanship of Admiral Sir Robert Burnett. Its powers were formidable, yet its first annual report, in spring 1952, stated that it had considered and rejected the possibility of drawing up a comprehensive plan for the industry. ${ }^{151}$ The radical reorganisation its founders had envisaged never happened, although in later years it did become a major force in fisheries research and development both in Britain and overseas, in addition to mounting large-scale promotional campaigns. ${ }^{152}$ In 1981 it was merged with the Herring Industry Board, whose raison d'être had disappeared with the collapse of the herring fisheries, to create the Sea Fish Industry Authority. Seafish, as it is now known, was shorn of many of its 
predecessors' 'dictatorial powers,' but remains a force in fisheries research, policy development and publicity. ${ }^{153}$

For all the debate over reorganisation, however, the subsidies which were quietly and uncontroversially introduced in 1948, and then continued under the 1951 Act, proved to be the most important legacy of the crisis. Britain belatedly joined other countries in subsidising its fisheries, and has done so ever since. Subsidies were intended to be temporary, to continue only until the White Fish Authority had reorganised the industry to the point where it could stand on its own feet. Yet no-one specified how long this was expected to take, and it receded further and further into the distance. The subsidy was essential to the economics of many of the near-and middle-water vessels, some of whose owners immediately began to press for more. ${ }^{154}$ Subsidies thus continued on a nominally time-limited basis throughout the 1950s, and were confirmed for a further ten years by a major enquiry chaired by Sir Alexander Fleck, which reported in 1961. By this time the distantwater fleet had also begun to lose money again, and was duly included. ${ }^{155}$ This time, though, a definite date was set by which it was expected the industry should be able to operate without subsidy. The Fleck Committee's recommendation, put into effect by Act of Parliament the following year, was that subsidies would taper away over ten years. ${ }^{156}$ The timescale was later lengthened by two years, but operating subsidies did indeed cease in July 1973, although the inshore fleet remained subsidised and grants for modernisation, new building and training in the deep sea fleet continued. ${ }^{157}$ However, the oil crisis and subsequent inflation of the early 1970 s, coupled with loss of access to distant-water grounds and the protracted process of drawing up the European Common Fisheries Policy, hit the industry hard, and operating subsidies were reintroduced in $1975 .{ }^{158}$ Since then, in Britain as elsewhere, they have 'settled in' and become politically extremely difficult to remove, and they remain to the present day. ${ }^{159}$

The period between 1945 and 1951, then, saw far-reaching changes across the deep-sea fishing industry, and the beginnings of some key aspects of modern fisheries policy. Some of this was occasioned by stock depletion and disputes over access to fishing grounds which are the best known aspects of the industry's twentieth-century history. Yet the question of the industry's organisation was closely linked with these, and for much of the twentieth century was equally important. 


\section{Bibliography}

Anyanova, E. 'Rescuing the Inexhaustible: The Issue of Fisheries Subsidies in the International Trade Policy.' Journal of International Commercial Law and Technology 3 (2008), 147-56.

Arnason, R.A., K. Kelleher and R. Willmann, The Sunken Billions: The Economic Justification for Fisheries Reform. Washington DC: World Bank, 2009.

Ashworth, W., The State in Business, 1945 to the mid-1980s. Basingstoke: Macmillan, 1991.

Atkins, J., The Distribution of Fish. London: Fabian Society, 1941.

Bjornsson, O., 'The Icelandic Fisheries,' in Atlantic Ocean Fisheries, ed. G. Borgstrom and A.J. Heighway, 260-6. London: Fishing News International, 1961.

British Trawlers Federation, Report on the British Fishing Industry: Distant Water Trawlers, 1956. Hull: British Trawlers Federation, 1957.

Chaloner, W.H. 'Trends in Fish Consumption in Great Britain from about 1900 to the Present Day,' Fish in Britain: Trends in its Supply, Distribution and Consumption during the Past Two Centuries, ed. T.C. Barker and J. Yudkin, 83-9. London: Queen Elizabeth College, 1971.

Cheap Food League, Your Fish: A Comment on Monopoly. London: Cheap Food League, 1952.

Chick, M. Industrial Policy in Britain 1945-1951. Cambridge: Cambridge University Press, 1998.

Cutting, C.L. Fish Saving: A History of Fish Processing from Ancient to Modern Times. London: L. Hill, 1955.

Daunton, M. Wealth and Welfare: An Economic and Social History of Britain 1851-1951 Oxford: Oxford University Press, 2007.

Findlay, R. and K.H. O'Rourke, Power and Plenty: Trade, War and the World Economy in the Second Millennium. Princeton NJ: Princeton University Press, 2007.

Garrido, A. 'The Portuguese New State and the Multilateral Management of Fisheries: Science, Law and Diplomacy (1948-1974),' e-Journal of Portuguese History 3:2 (2005).

Garstang, W. 'The Impoverishment of the Sea: A Critical Summary of the Experimental and Statistical Evidence bearing upon the Alleged Depletion of the Trawling Grounds,' Journal of the Marine Biological Association 6:1` (1900), 1-69.

Goodlad, J. 'Sectoral Quota Management: Fisheries Management by Fish Producer Organizations,' in The Politics of Fishing, ed. T.S. Gray, 146-60. Basingstoke: Palgrave Macmillan, 1998.

Great Britain, Economic Advisory Council, Committee on the Fishing Industry. London: HMSO, 1932. 
Great Britain, Parliament, Report of Inquiry into the Fishing Industry. London: HMSO, 1961

Great Britain, Sea Fish Commission, Second Report: The White Fish Industry. London: HMSO, 1936.

Hubbard, J. 'Changing Regimes: Governments, Scientists and Fishermen and the Construction of Fisheries Policies in the North Atlantic, 1850-2010,' in A History of the North Atlantic Fisheries, vol. 2: From the 1850s to the Early Twenty-First Century, ed. D.J. Starkey and I. Heidbrink, 129-76. Bremerhaven: Deutsches Schiffahrtsmuseum, 2012.

Irving, H. 'The Birth of a Politician: Harold Wilson and the Bonfires of Controls, 1948-9.' Twentieth Century British History (2013), doi:10.1093/tcbh/hws044.

Kelsall, R.K., H. Hamilton, F.A. Wells and K.C. Edwards, 'The White Fish Industry,' Further Studies in Industrial Organisation, ed. M.P. Fogarty, 101-70. London: Methuen \& Co, 1948.

Jóhannesson, G. Troubled Waters: Cod War, Fishing Disputes and Britain's Fight for Freedom of the High Seas, 1948-1964. Reykjavik: North Atlantic Fisheries History Association, 2007.

Jóhannesson, G. "'Life is Salt Fish": The Fisheries of the Mid-Atlantic Islands in the Twentieth Century,' in A History of the North Atlantic Fisheries, vol. 2: From the 1850s to the Early Twenty-First Century, ed. D.J. Starkey and I. Heidbrink, 277-92. Bremerhaven: Deutsches Schiffahrtsmuseum, 2012.

March, E.J. Sailing Trawlers: The Story of Deep-Sea Fishing with a Long Line and Trawl. Newton Abbot: David \& Charles, 1970.

Middleton, R. Government versus the Market: The growth of the public sector, economic management and British economic performance, c.1890-1979. Cheltenham: Edward Elgar, 1996.

Morgan, K.O. Labour in Power, 1945-51. Oxford: Oxford University Press, 1985.

Organisation for European Economic Cooperation, Fishery Policies in Western Europe and North America. Paris: Organisation for European Economic Cooperation, 1960),

Reid, C. 'Managing Innovation in the British Herring Fishery: the role of the Herring Industry Board 1945-77,' Marine Policy 22 (1998), 281-95.

Reid, C. 'From Boom to Bust: The Herring Industry in the Twentieth Century,' in England's Sea Fisheries: The Commercial Sea Fisheries of England and Wales since 1300, ed. D.J. Starkey, C. Reid and N. Ashcroft, 168-96. London: Chatham Publishing, 2000.

Reid, C. "'A Common Delicacy:" UK Fish Consumption in the Twentieth Century,' in Politics and People in the North Atlantic Fisheries since 1485, ed. D.J. Starkey, P. Holm, J. Th. Thór and B. Andersson, 168-88. Hull: North Atlantic Fisheries History Association, 2003. 
Reid, C. and Søndergaard, M.K. 'Bilateral Trade and Fisheries Development: the Anglo-Danish Trade Agreement, 1933,' Scandinavian Journal of History 37 (2012), 108-128.

Robinson, A. 'The economic problems of the transition from war to peace: 1945-49,' Cambridge Journal of Economics 10 (1986), 165-85.

Robinson, R. Trawling: The Rise and Fall of the British Trawl Fishery. Exeter: Exeter University Press, 1996.

Robinson, R. 'The Development of the British Distant Water Trawling Industry, 1880-1939,' in Exploiting the Sea: Aspects of Britain's Maritime Economy since 1870, ed. D.J. Starkey and A.G. Jamieson, 148-66. Exeter: Exeter University Press, 1998.

Robinson, R. 'Hook, Line and Sinker: Fishing History - where we have been, where we are now and where are we going?' Mariner's Mirror 97 (2011), 167-179.

Robinson, R. 'The North Sea Littoral and the British Isles,' ' in A History of the North Atlantic Fisheries, vol. 2: From the 1850s to the Early Twenty-First Century, ed. D.J. Starkey and I. Heidbrink, 238-52. Bremerhaven: Deutsches Schiffahrtsmuseum, 2012.

Starkey, D.J. and R. Robinson, 'The Sea Fisheries of the British Isles, 1376-1976: A Preliminary Survey,' in The North Atlantic Fisheries, 1100-1976: National Perspectives on a Common Resource, ed. P. Holm, D.J. Starkey and J. Th. Thór, 121-43. Esbjerg: North Atlantic Fisheries History Association, 1996.

Thomas-Symonds, N. Attlee: A Life in Politics. London: I.B. Tauris, 2010.

Thomson, P.A.B. "Brixham Sailing Trawlers: The Last Years of a Working Fleet,' Mariner's Mirror 88 (2002), 176-185.

Thór, J. Th. British Trawlers and Iceland 1919-1976. Göteborg: Göteborgs universitet, 1995.

Tiratsoo, N. and J. Tomlinson, Industrial Efficiency and State Intervention: Labour 1939-1951. London: Routledge, 1993.

Tomlinson, J. Public Policy and the Economy since 1900. Oxford: Clarendon press, 1990.

Tomlinson, J. 'Mr Attlee's Supply-Side Socialism,' Economic History Review 46 (1993), 1-22.

Tomlinson, J. Democratic Socialism and Economic Policy. Cambridge: Cambridge University Press, 2002.

Tunstall, J. The Fishermen: The Sociology of an Extreme Occupation. London: Macgibbon \& Kee, 1962. 
White Fish Authority, First Annual Report and Accounts for the period ended 31 $31^{\text {st }}$ March 1952. London: White Fish Authority, 1952.

White Fish Authority, Fourth Annual Report and Accounts for the period ended $31^{\text {st }}$ March 1955. London: White Fish Authority, 1955.

White Fish Authority, Fish: From the Sea to the Table. London: White Fish Authority, c.1958.

White Fish Authority, Twenty-Third Annual Report and Accounts for the period ended $31^{\text {st }}$ March 1974. Edinburgh: White Fish Authority, 1974.

White Fish Authority, Twenty-Fourth Annual Report and Accounts for the period ended $31^{\text {st }}$ March 1975. Edinburgh: White Fish Authority, 1975.

Wilcox, M. 'Concentration or Disintegration? Vessel Ownership, Fish Wholesaling and Processing in the British Trawl Fishery, 1850-1939,' in The North Atlantic Fisheries: Supply, Marketing and Consumption, 1560-1990. Hull: North Atlantic Fisheries History Association, 2006.

Wilcox, M. 'Beyond the North Atlantic' in A History of the North Atlantic Fisheries, vol. 2: From the 1850s to the Early Twenty-First Century, ed. D.J. Starkey and I. Heidbrink, 306-26. Bremerhaven: Deutsches Schiffahrtsmuseum, 2012.

Wilcox, M. 'Railways, Roads and the British White Fish Industry, 1920-70,' Business History 54 (2012), 741-764.

Wilson, J.F. British Business History, 1720-1994. Manchester: Manchester University Press, 1995.

Zweininger-Bargielowska, I. Austerity in Britain: Rationing, Controls and Consumption 1939-1955. Oxford: Oxford University Press, 2002. 
${ }^{1}$ Suffolk Record Office (hereafter SRO), 1757/2/2, Lowestoft Fishing Vessel Owners' Association (hereafter LFVOA), Directors' Minutes, 9 May 1950.

${ }^{2}$ For a recent critical review of the literature see Robinson, 'Hook, Line and Sinker;' for an earlier look at the state of fisheries history see Starkey and Robinson, 'Sea Fisheries of the British Isles.

${ }^{3}$ Robinson, Trawling.

${ }^{4}$ Personal Communication: conversation with Mr David Hudson (Hudson Bros. Trawlers) and Mr M. Jonathan Watson Hall (Thomas Hamling \& Co), 3 October 2016.

${ }^{5}$ Robinson, Trawling, 147; Thomson, 'Brixham Sailing Trawlers,' 176-85; March, Sailing Trawlers, 173; Great Britain, Sea Fisheries Statistical Tables, 1938.

${ }^{6}$ White Fish Authority, Fish: From the Sea to the Table; The National Archives: Public Record Office (hereafter TNA: PRO), MAF 209/709, Re-organisation of the white fish industry: 'Present Position of the Industry,' undated but probably c.25 May 1950.

${ }^{7}$ See Great Britain, Sea Fisheries Statistical Tables, 1938.

${ }^{8}$ Sea Fish Commission, Second Report (hereafter 'Duncan Commission'), 19-20.

${ }^{9}$ Wilcox, 'Concentration or Disintegration?' 62.

${ }^{10}$ Kelsall et al, 'The White Fish Industry,' PAGE

${ }^{11}$ Duncan Commission, 54.

${ }^{12}$ Hansard, HC Deb 27 April 1950 vol 474 cc1174-262.

${ }^{13}$ Wilcox, 'Railways, Roads and the British White Fish Industry,' 741-64.

${ }^{14}$ Duncan Commission, 15.

${ }^{15}$ Robinson, Trawling, 146.

${ }^{16}$ Duncan Commission, 17.

${ }^{17}$ Garstang, 'Impoverishment of the Sea.'

${ }^{18}$ Duncan Commission, 36-41; British Parliamentary Papers (hereafter BPP) 1920 XXIII, Profiteering Act, 1919. Findings by a committee appointed to enquire into the fish trade.

${ }^{19}$ Duncan Commission, 10-1.

${ }^{20}$ Robinson, Trawling, 151; Robinson, 'Development of the British Distant Water Trawling Industry,' 148-66; see also note 3 .

${ }^{21}$ Duncan Commission, 14, 18, 25-6, 39; see also Kelsall et al, 'The White Fish Industry,' 101-71.

${ }^{22}$ Duncan Commission, 14.

${ }^{23}$ Maritime Historical Studies Centre, University of Hull, Hull Fish Merchants' Protection Association (hereafter HFMPA), Minutes, 29 May and 5 June 1931. These records have since the time of writing been transferred to Hull History Centre. They are as yet uncatalogued, and therefore are referenced by date only.

${ }^{24}$ Hansard, HC Deb 18 Nov 1937, vol. 329, cc597-713. See especially the comments of Douglas Thomson (Aberdeen South), George Garro-Jones (Aberdeen North) and Pierse Loftus (Lowestoft).

${ }^{25}$ TNA:PRO, MAF 23/3/3, White Fish Commission: Signed Minutes of the Meetings of the White Fish Commission, Ninth Meeting, 24 Mar 1939.

${ }^{26}$ Economic Advisory Council, 39.

${ }^{27} 23$ \& 24 Geo 5, Ch.45; Duncan Commission, 10-1; Robinson, Trawling, 159-60.

${ }_{28}^{28}$ Reid and Sondergaard, 'Bilateral Trade and Fisheries Development,'109-12.

${ }^{29}$ Middleton, Government versus the Market, 369; Daunton, Wealth and Welfare, 63-4; Duncan Commission, 68.

${ }^{30}$ Reid, 'Boom to Bust,' 193; Reid, 'Managing Innovation,' 281-2.

${ }^{31} 1$ \& 2 Geo. 6, Ch.30.

${ }^{32}$ British Parliamentary Papers (hereafter BPP), 1938-9 XIV, 161-215, Report of the Departmental Committee on the Imposition of Penalties by Marketing Boards and other Similar Bodies. See also TNA: PRO, MAF 23/1/5, White Fish Commission: Fishmongers' Marketing Scheme, 1938.

${ }^{33}$ Hubbard, 'Changing Regimes,' 138-9; Garrido, 'The Portuguese New State.'

${ }^{34}$ Duncan Commission, 67.

${ }^{35}$ TNA: PRO, MAF 23/3/6, White Fish Commission: First Annual Report, 1939.

${ }^{36}$ Robinson, Trawling, 176.

${ }^{37}$ Sea Fisheries Statistical Tables, 1939-44. 
${ }^{38}$ TNA: PRO, MAF 255/544. Sea Fish Industry Bill 1951. Note for Minister on Price Controls, 18 Dec 1950; Atkins, The Distribution of Fish, 8-10; Maritime Historical Studies Centre, University of Hull (hereafter MHSC), HFMPA (hereafter HFMPA), Minutes, 1 Oct 1942.

${ }^{39}$ Sea Fisheries Statistical Tables, 1939-44; Atkins, Distribution of Fish, 11.

${ }^{40}$ Zweininger-Bargielowska, Austerity in Britain, 77.

${ }^{41}$ See Tomlinson, Democratic Socialism; Thomas-Symonds, Attlee, 199-210; Morgan, Labour in Power.

${ }^{42}$ Examples at this time included Edward Evans (Lab, Lowestoft), Robert Boothby (Con, Aberdeen and Kincardine East), Hector Hughes (Lab, Aberdeen North) and Harry Pursey (Lab, Kingston upon Hull East).

${ }^{43}$ Hull History Centre (hereafter HHC), C DBHB/5/10, Kingston Steam Trawling Company (hereafter KST), Directors' Minutes, 19 May 1943, 17 Jan 1945, 16 Feb 1949.

${ }^{44}$ Sea Fisheries Statistical Tables, 1945 and 1948.

45 TNA: PRO, MAF 209/709, Re-organisation of the white fish industry. 'Present Position of the Industry,' undated but probably c.25 May 1950; Cutting, Fish Saving, 267.

${ }^{46}$ MHSC, HFMPA Minutes, 9 October 1946.

${ }^{47}$ HHC, C DBHB/5/10, KST, Directors' Minutes, 21 May 1947, 22 Mar 1949.

${ }^{48} \mathrm{HHC}, \mathrm{C}$ DBHB/5/10, KST, Directors' Minutes, 21 Jul 1948, 17 May 1950; Tunstall, The Fishermen, 238-44.

${ }^{49}$ Robinson, Trawling, 187; SRO, 1757/2/2, LFVOA, Directors' Minutes, 6 Mar 1948.

${ }^{50}$ Sea Fisheries Statistical Tables, 1938, 1947 and 1948. These figures do not include re-exports.

${ }^{51}$ Zweininger-Bargielowska, Austerity in Britain, 38; Chaloner, 'Trends in Fish Consumption,' 83; MHSC, HFMPA, Extraordinary General Meeting, 12 Dec 1949.

${ }^{52}$ MHSC, HFMPA, Annual General Meetings, 12 Jun 1945, 27 Jun 1947 and 22 Jun 1948.

53 Irving, 'The Birth of a Politician.'

${ }^{54}$ MHSC, HFMPA, Annual General Meeting, 27 Jun 1947.

${ }^{55}$ Daunton, Wealth and Welfare, 598; Wilson, British Business History, 198.

${ }^{56}$ SRO, 1757/2/2, LFVOA, Directors' Minutes, 7 Oct 1948.

${ }^{57}$ MHSC, HFMPA, Annual General Meeting, 2 Jun 1949.

${ }^{58}$ SRO, 1757/2/2, LFVOA, Directors' Minutes, 12 Aug 1948, 17 Nov 1949; MHSC, HFMPA, Extraordinary General Meeting, 12 Dec 1949.

5911 \& 12 Geo. 6, c.51.

${ }^{60}$ Hubbard, 'Changing Regimes,' 142-3; Organisation for European Economic Cooperation, Fishery Policies, 85.

${ }^{61}$ Jóhannesson, Troubled Waters, 22; Thór, British Trawlers and Iceland, 142-7; Wilcox, 'Beyond the North Atlantic,' 307-9.

${ }^{62}$ Robinson, Trawling, 228.

63 Jóhannesson, Troubled Waters, 41-51, 64-8.

${ }^{64}$ SRO, 1757/2/2, LFVOA, Directors' Minutes, 13 Aug 1948.

${ }^{65}$ White Fish Authority, First Annual Report, 11.

${ }^{66}$ SRO, 1757/2/2, LFVOA, Directors' Minutes, 30 Nov 1948; Hubbard, 'Changing Regimes,' 138.

${ }^{67}$ Consumption of all fish fell from 31.2lb per head in 1948 to 27.4 in 1949 and 21.7 in 1950. See Chaloner, 'Trends in Fish Consumption,' 88.

68 TNA: PRO, MAF 209/709, Re-organisation of the White Fish Industry: Interdepartmental Conference, 19 May 1950; Cabinet Memorandum by the Secretary of State for Scotland, Minister of Agriculture and Fisheries and the Minister of Food, 19 Jun 1950.

${ }^{69}$ The Economist, 29 Apr 1950, quoted in Reid, "'A Common Delicacy," 174.

70 TNA: PRO, MAF 209/709, Re-organisation of the white fish industry. 'Present Position of the Industry,' undated but probably c.25 May 1950.

71 TNA: PRO, MAF 209/709, Re-organisation of the white fish industry. 'Position of the White Fish Industry,' Cabinet Memorandum, 18 Apr 1950.

72 TNA: PRO, MAF 255/544. Sea Fish Industry Bill 1951. Note for Minister on Price Controls, 18 Dec 1950

${ }^{73}$ SRO, 1757/2/2, LFVOA, Directors' Minutes, 27 Oct 1948.

${ }^{74}$ MHSC, HFMPA, Extraordinary General Meeting, 9 Mar 1950.

75 TNA: PRO, MAF 209/709, Re-organisation of the white fish industry. Minute Sheet, see 18 Apr 1950.

${ }^{76}$ Hansard, HC Deb 27 April 1950 vol 474 cc1174-262.

77 TNA: PRO, MAF 209/709, Re-organisation of the white fish industry. 'Present Position of the Industry,' undated but probably c.25 May 1950.

${ }^{78}$ Hansard, HC Deb 27 April 1950 vol 474 cc1174-262; SRO, 1757/2/2, LFVOA, Directors' Minutes, 9 May 1950. 
${ }^{79}$ TNA: PRO, MAF 209/751, Reorganisation of white fish industry: short term remedies. Note by Ministry of Agriculture and Fisheries, 25 May 1950.

${ }^{80}$ SRO, 1757/2/2, LFVOA, Directors' Minutes, 22 May 1950.

${ }^{81}$ TNA: PRO, MAF 209/709, Re-organisation of the white fish industry. Minute Sheet, see 19 Jun 1950.

${ }^{82}$ TNA: PRO, MAF 209/751, Reorganisation of white fish industry: short term remedies. Report of Official Committee, undated but c. Jun 1950.

${ }^{83}$ HHC, C DBHB/5/10, KST, Directors' Minutes, 16 Aug 1950; SRO, 1757/2/3, LFVOA, Directors' Minutes, 7 Feb 1951.

${ }^{84}$ Sea Fisheries Statistical Tables, 1950.

${ }^{85}$ TNA: PRO, MAF 209/751, Reorganisation of white fish industry: short term remedies. Report of Official Committee, undated but c. Jun 1950; Minutes of Interdepartmental Conference, 19 May 1950.

${ }^{86}$ TNA: PRO, MAF 209/722, Distant Water Vessels Development Scheme: British Housewives' League to Minister of Agriculture and Fisheries, 25 Mar 1952; Cheap Food League, Your Fish; The People, 2 Mar 1952

${ }^{87}$ TNA: PRO, MAF 209/751, Reorganisation of white fish industry: short term remedies, Note by Ministry of Agriculture and Fisheries, 25 May 1950.

${ }^{88}$ TNA: PRO, MAF 209/751, Reorganisation of the white fish industry: short term remedies. Draft letter for signature by the Minister, undated.

${ }^{89}$ Hansard, HC Deb 27 April 1950 vol 474 cc1174-262; TNA: PRO, MAF 209/751, Reorganisation of white fish industry: short term remedies. Notes of meeting of officials, 2 Jun 1950.

${ }^{90}$ TNA: PRO, MAF 209/709, Re-organisation of the white fish industry. P.D.H. Dunn to R. Herbert, 17 May 1950.

${ }^{91}$ BPP 1945-6 XII, Report of a Court of Inquiry into the Circumstances and Causes of the Stoppage of Work in the Trawler Fishing Industry, 147-61.

${ }^{92}$ HHC, C DBHB/5/10, KST, Directors' Minutes, 16 Jul 1946; SRO, 1757/2/2, LFVOA, Directors' Minutes, 24 Feb 1950.

${ }^{93}$ SRO, 1757/2/2, LFVOA, Directors' Minutes, 9 May 1950.

${ }^{94}$ TNA: PRO, MAF 209/751, Reorganisation of white fish industry: short term remedies, Note by Ministry of Agriculture and Fisheries, 25 May 1950.

${ }^{95}$ MHSC, HFMPA, Annual General Meeting, 12 Jul 1950; Jóhannesson, Troubled Waters, 54.

${ }^{96}$ MHSC, HFMPA, Extraordinary General Meeting, 5 Mar 1947.

${ }^{97}$ MHSC, HFMPA Minutes, 12 Dec 1949, Extraordinary General Meeting, 12 Apr 1950.

${ }^{98}$ HHC, C DBHB/5/10, KST, Directors' Minutes, 19 Sept 1945, 17 Mar 1950.

${ }^{99}$ TNA: PRO, MAF 209/722, Distant Water Vessels Development Scheme, Hull and Grimsby Long-Distance Water Owners to P.D.H. Dunn, 13 Jul 1950.

${ }^{100}$ TNA: PRO, MAF 209/722, Distant Water Vessels Development Scheme, Management Committee to

Fleetwood Fishing Vessel Owners' Association, 13 Jul, 9 Sep 1950.

${ }^{101}$ British Trawlers Federation (hereafter BTF), Distant Water Trawlers, 1956, 21-3.

${ }^{102}$ TNA: PRO, MAF 209/722, Distant Water Vessels Development Scheme, Final Text of Scheme, 12 Jul 1951.

${ }^{103}$ White Fish Authority, Fourth Annual Report, 37.

${ }^{104}$ Robinson, Trawling, 188-9;BTF, Distant Water Trawlers, 6,

${ }^{105}$ Sea Fisheries Statistical Tables, 1950.

${ }^{106}$ TNA: PRO, MAF 209/709, Re-organisation of the white fish industry. 'Position of the White Fish Industry,' Cabinet Memorandum, 18 Apr 1950; Cabinet Memorandum by the Secretary of State for Scotland, Minister of Agriculture and Fisheries and the Minister of Food, 19 Jun 1950; SRO, 1757/2/2, LFVOA, Directors' Minutes, 22 May 1950.

${ }^{107}$ TNA: PRO, MAF 209/709, Re-organisation of the white fish industry. Minute Sheet, see 18 Apr 1950.

${ }^{108}$ TNA: PRO, MAF 209/709, Re-organisation of the White Fish Industry: Interdepartmental Conference, 19 May 1950.

${ }^{109}$ Bjornsson, 'The Icelandic Fisheries,' 266; Jóhannesson, "'Life is Salt Fish," 56.

110 Jóhannesson, Troubled Waters, 51-63; TNA: PRO, MAF 209/709, Re-organisation of the White Fish Industry: Foreign Office to P.D.H. Dunn, 31 May 1950.

${ }^{111}$ Tomlinson, Democratic Socialism, 24-9.

${ }^{112}$ Findlay and O'Rourke, Power and Plenty, 491.

${ }^{113}$ TNA: PRO, MAF 209/751, Reorganisation of white fish industry: short term remedies. J. Leckie (Foreign Office) to P.D.H. Dunn, 26 May 1950. 
${ }^{114}$ TNA: PRO, MAF 209/709, Re-organisation of the White Fish Industry: Foreign Office to P.D.H. Dunn, 31 May 1950.

115 TNA: PRO, MAF 209/709, Re-organisation of the white fish industry. 'Position of the White Fish Industry,' Cabinet Memorandum, 18 Apr 1950; White Fish Authority, First Annual Report, 9.

${ }^{116}$ See for example the remarks of Robert Boothby: Hansard, HC Deb 27 April 1950 vol 474 cc1160-73.

${ }^{117}$ TNA: PRO, MAF 209/709, Re-organisation of the White Fish Industry: Cabinet Memorandum by the Secretary of State for Scotland, Minister of Agriculture and Fisheries and the Minister of Food, 19 Jun 1950.

118 TNA: PRO, MAF 209/751, Reorganisation of white fish industry: short term remedies. Report of Official Committee, undated but c. Jun 1950; Notes of meeting of officials, 2 Jun 1950.

${ }^{119}$ TNA: PRO, MAF 209/709, Re-organisation of the White Fish Industry: Interdepartmental Conference, 19 May 1950. See remarks by P.D.H. Dunn.

${ }^{120}$ TNA: PRO, MAF 209/751, Reorganisation of white fish industry: short term remedies. Report of Official Committee, undated but c. Jun 1950; Notes of meeting of officials, 2 Jun 1950.

${ }^{121}$ Hansard, HC Deb 04 July 1950 vol 477 cc236-42, see comments by Hector Hughes; HC Deb 25 January 1951 vol 483 cc322-433, see remarks by Captain Mark Hewitson (Lab, Hull Central).

122 TNA: PRO, MAF 209/709, Re-organisation of the white fish industry. 'Present Position of the Industry,' undated but probably c.25 May 1950; Ashworth, The State in Business, 9-11.

${ }^{123}$ HHC, C DBHB/5/10, KST, Directors' Minutes. On 22 Oct 1947 Kingston's directors determined to donate $£ 200$ to the local Conservative Party, to be anonymous unless other Hull firms moved to declare their support openly. This evidently did not happen, for on 15 Sep 1948 they made another anonymous $f 100$ donation. On 17 Aug 1949 an appeal for funds by the Economic League, to which Kingston was a regular donor, was left on the table pending possible combined action by the Hull Fishing Vessel Owners' Association. This did not materialise, and on 21 Dec 1949 Kingston donated $£ 50$.

${ }^{124}$ HHC, C DBHB/5/10, KST, Directors' Minutes, 21 Feb 1951.

125 TNA: PRO, MAF 209/709, Re-organisation of the white fish industry. 'Position of the White Fish Industry,' Cabinet Memorandum, 18 Apr 1950; MHSC, HFMPA, Annual General Meeting, 27 Jun 1947.

${ }^{126}$ Hansard, HC Deb 12 November 1947 vol 444 cc495-516, see speech by Douglas Marshall (Con, Bodmin). ${ }^{127}$ TNA: PRO, MAF 209/709, Re-organisation of the White Fish Industry: Interdepartmental Conference, 19 May 1950. See remarks by P.D.H. Dunn.

${ }^{128}$ Tiratsoo and Tomlinson, Industrial Efficiency and State Intervention, 81-4.

${ }^{129}$ TNA: PRO, MAF 209/709, Re-organisation of the White Fish Industry: Interdepartmental Conference, 19 May 1950; Cabinet Memorandum by the Secretary of State for Scotland, Minister of Agriculture and Fisheries and the Minister of Food, 19 Jun 1950.

${ }^{130}$ Tomlinson, Democratic Socialism, 68-9; Tomlinson, 'Mr Attlee's Supply-Side Socialism'; Chick, Industrial Policy; Middleton, Government versus the Market, 468.

${ }^{131}$ TNA: PRO, MAF 209/772, White Fish Authority: consideration of powers and functions. White Fish Industry Board: Powers Required, 14 Jul 1950.

132 TNA: PRO, MAF 255/544, Sea Fish Industry Bill 1951. Note for Minister, 17 Jan 1951; SRO, 1757/2/3, LFVOA, Directors' Minutes, 19 Feb 1951.

${ }^{133}$ TNA: PRO, AY 8/63, Humber Laboratory: establishment of new research station on the Humber. Draft proposal by G.A. Reay for Hull Laboratory, 7 Oct 1948.

${ }^{134}$ Tomlinson, 'Mr Attlee's Supply-Side Socialism,' 3-4.

135 TNA: PRO, MAF 209/772, White Fish Authority: consideration of powers and functions. White Fish Industry Board: Powers Required, 14 Jul 1950.

${ }^{136}$ Hansard, HC Deb 04 July 1950 vol 477 cc236-42.

13714 \& 15 Geo. VI, Ch. 30.

${ }^{138}$ SRO, 1757/2/3, LFVOA, Directors' Minutes, 7 Feb 1951.

${ }^{139}$ SRO, 1757/2/3, LFVOA, Directors' Minutes, 12 Apr 1951.

${ }^{140}$ MHSC, HFMPA Minutes, 5 Oct 1950, 30 Jul 1951.

${ }^{141}$ MHSC, Federation of British Port Wholesale Fish Merchants' Associations Minutes, 13 Jul 1951.

142 TNA: PRO, MAF 255/544. Sea Fish Industry Bill 1951. Notes for Minister for Third Reading, undated; Hansard, HC Deb 04 July 1950 vol 477 cc236-42, see remarks by Hector Hughes; HC Deb 25 Jan 1951 vol 483 cc322-433, see speeches by Cyril Osborne (Con, Louth). See also MHSC, HFMPA Minutes, 18 Jan 1951: R.K. Law (Con, Haltemprice), believed the Sea Fisheries Act 1951 'appeared to give as wide powers as a Nationalisation Bill.' 
${ }^{143}$ TNA: PRO, MAF 209/751, Reorganisation of white fish industry: short term remedies, Note by Ministry of Agriculture and Fisheries, 25 May 1950; World Fishing, Sept 1952; see also Table 1.

${ }^{144}$ SRO, 1757/2/3, LFVOA, Directors' Minutes, 20 Jun 1951.

${ }^{145}$ Hansard, HC Deb 27 Nov 1950 vol 481 c103W. See speeches by Barnett Janner and Mrs Jean Mann; see also TNA: PRO, MAF 255/544. Sea Fish Industry Bill 1951. Note for Minister on Price Controls, 18 Dec 1950. ${ }^{146}$ Hansard, HC Deb 19 Feb 1951 vol 484 cc864-6; World Fishing, Sept 1952.

${ }^{147}$ http://ec.europa.eu/fisheries/cfp/market/producer_organisations/index_en.htm, accessed 7 Feb 2014.

148 Goodlad, 'Sectoral Quota Management,' 146-59.

${ }^{149}$ Robinson, Trawling, 244-9.

${ }^{150}$ Robinson, 'Economic Problems,'

${ }^{151}$ White Fish Authority, First Annual Report, 6.

${ }^{152}$ TNA: PRO, MAF 209/3182, Review of the White Fish Authority and Herring Industry Board. Submission to Minister, 26 Sept 1980.

${ }^{153}$ http://www.seafish.org/about-seafish, accessed 4 Feb 2016.

${ }^{154}$ SRO, 1757/2/3, LFVOA, Directors' Minutes, 20 Jun, 12 Jul 1951.

${ }^{155}$ Great Britain, Parliament, Report of Inquiry into the Fishing Industry.

${ }^{156} 10$ \& 11 Elizabeth 2, Ch.31.

${ }^{157}$ White Fish Authority, Twenty-Fourth Annual Report, 3.

${ }^{158}$ White Fish Authority, Twenty-Third Annual Report, 16.

${ }^{159}$ Anyanova, 'Rescuing the Inexhaustible,' 147-56; see also Arnason et al, Sunken Billions. 